\title{
STRATEGI ADAPTASI PERUBAHAN IKLIM PADA PETANI DATARAN TINGGI (Studi Petani di Dataran Tinggi Dieng, Kabupaten Banjarnegara)
}

\author{
Climate Change Adaptation Strategy of Upland Farmers \\ (Study of Farmers in Dieng Plateau, Banjarnegara Regency)
}

\author{
Turasih*), Lala M.Kolopaking, dan Ekawati Sri Wahyuni \\ Departemen Sains Komunikasi dan Pengembangan Masyarakat, Fakultas Ekologi Manusia IPB \\ *)E-mail: turasih@gmail.com
}

\begin{abstract}
Climate change in the Dieng Plateau area is characterized into five local climatic phenomenon: (1) extreme rainfalls, (2) drought in agriculture, (3) hurricans, (4) extreme temperature, and (5) the unpredictable season. Farmers adaptation strategy towards those adverse impacts is identified by occupation of agriculture land. This land occupation also determines access to capital and intensity level of climate change vulnerability. If a farmer household occupies larger lands, so the access to capital is also more and the intensity level of climate change vulnerability becomes lower. On the contrary, smaller lands occupied leaves farmer households with low access to capital and high climate change vulnerability.
\end{abstract}

Keywords: climate change, adaptation strategy, vulnerability, farmer household

\begin{abstract}
ABSTRAK
Perubahan iklim di Dataran Tinggi Dieng ditandai oleh lima fenomena iklim lokal yaitu: (1) curah hujan yang semakin ekstrem, (2) kekeringan yang melanda pertanian, (3) angin ribut, (4) suhu ekstrem, dan (5) musim yang sulit diprediksi. Strategi adaptasi untuk menghadapi kondisi iklim tersebut dilakukan oleh rumah tangga petani berdasarkan tingkat penguasaannya terhadap lahan pertanian. Luas lahan pertanian yang dikuasai oleh rumah tangga menentukan akses terhadap modal dan intensitas tingkat kerentanan terhadap perubahan iklim. Semakin luas lahan yang dikuasai oleh rumah tangga petani maka nilai akses terhadap modal relatif lebih tinggi dan tingkat kerentanannya terhadap perubahan iklim semakin rendah. Sebaliknya, Semakin luas lahan yang dikuasai oleh rumah tangga petani maka nilai akses terhadap modal akan semakin rendah dan tingkat kerentanannya terhadap perubahan iklim semakin tinggi.
\end{abstract}

Kata kunci: perubahan iklim, strategi adaptasi, kerentanan, rumah tangga petani

\section{PENDAHULUAN}

Perubahan iklim yang mempengaruhi pemanasan global telah dibuktikan secara ilmiah berdasarkan tren data peningkatan suhu di bumi. Data IPCC (2007) menjelaskan bahwa tahun 1995-2006 merupakan dekade dimana bumi berada dalam kondisi paling hangat berdasarkan rekaman data sejak tahun 1850. Peningkatan suhu berdasarkan tren data per seratus tahun sejak 1906-2005 menunjukkan bahwa terjadi peningkatan suhu mendekati dua kali lipat pada tahun 1956-2005. Peningkatan suhu tersebut mempengaruhi seluruh permukaan bumi terutama di kutub utara. Dalam kurun waktu 100 tahun ke belakang, suhu Antartika meningkat dua kali lipat dibanding suhu bumi rata-rata. Analisis ini juga menggambarkan pemanasan yang terjadi di seluruh bumi bahwa daratan lebih cepat panas dibanding lautan. Kenyataan tersebut menjadikan perubahan iklim sebagai keniscayaan sekaligus isu yang menjadi perhatian masyarakat global termasuk Indonesia.

Perubahan iklim global yang dicirikan oleh perubahan suhu udara permukaan bumi, curah hujan wilayah, limpasan permukaan,evapotranspirasi, simpanan air bumi dan sebagainya. Secaralangsung maupun tidak langsung berpengaruh terhadap respons hidrologi wilayah yangselanjutnya menentukan ketersediaan air wilayah untuk berbagai kebutuhan dan ikut menentukan nilai ekologi, sosial, dan ekonomi sumber daya air yang ada. Kerentanan daur hidrologi misalnya ditunjukkan oleh fakta bahwa perubahan $10 \%$ curah hujan benua hanya memerlukan perubahan $2 \%$ dari evaporasi lautan dan pembentukan gurun memerlukan perubahan jauh lebih kecil [0,2\% dari keseluruhan daur air] (Pawitan, 2010).

Berdasarkan data IPCC (2007) peningkatan suhu di Indonesia antara 1970-2004 sebesar $0,2^{\circ} \mathrm{C}-1^{\circ} \mathrm{C}$. Pada tahun 2009, Indonesia secara sukarela memberikan komitmennya untuk melakukan pengurangan emisi Gas Rumah Kaca (GRK) melalui aksi mitigasi. Komitmen tersebut difokuskan dalam lima sektor utama yaitu kehutanan dan lahan gambut, pertanian, energi dan transportasi, industri, dan limbah dengan target penurunan emisi sebesar $26 \%$ tanpa bantuan internasional dan sebesar $41 \%$ jika melibatkan bantuan internasional. Komitmen tersebut tertuang dalam Peraturan Presiden Nomor 61 tahun 2011 tentang Rencana Aksi Penurunan Emisi Gas Rumah Kaca dan didukung oleh Peraturan Presiden Nomor 71 tahun 2011 tentang Penyelenggaraan Inventarisasi Gas Rumah Kaca Nasional. Kemudian disadari bahwa berbagai fenomena kebencanaan terkait iklim semakin meningkat dalam frekuensi kejadian maupun amplitudo bencana yang sudah menimbulkan dampak negatif di berbagai sektor. Upaya mitigasi saja dirasa tidak cukup untuk mengatasi peningkatan dampak tersebut, sehingga dilakukan juga upaya adaptasi.

Hasil identifikasi program kegiatan adaptas dari DNPI (2012), menunjukkan persentase terbesar dari kegiatan/ 
program adaptasi perubahan iklim adalah pada tematik bidang manajemen risiko bencana $(31 \%)$ dan pertanian/ketahanan pangan $(31 \%)$, dan sisanya terbagi hampir merata pada pembangunan wilayah pesisir (13\%), kesehatan masyarakat $(6 \%)$, sumber daya dan kualitas air $(10 \%)$, dan pengelolaan sumber daya alam (5\%). Kegiatan/program adaptasi perubahan iklim yang paling dominan adalah pada jenis adaptasi terencana (48\%), diikuti oleh jenis adaptasi antisipatif (37\%), dan adaptasi otonom (14\%). Kegiatan/program adaptasi perubahan iklim masih didominasi oleh kegiatan adaptasi dengan dimensi kapasitas adaptif (73\%), diikuti aksi adaptasi (24\%) dan pembangunan berlanjut/lestari (2\%).

Pada sektor pertanian, kebijakan yang terkait dengan perubahan iklim yang berhubungan dengan petani dataran tinggi maupun petani komoditi selain padi sawah di Indonesia masih sangat minim. Peta jalan (road map) strategi sektor pertanian dalam menghadapi perubahan iklim tahun 20112014 yang dikeluarkan oleh Kementerian Pertanian (2010) lebih membahas upaya adaptasi dan mitigasi perubahan iklim yang sifatnya teknis dengan penekanan pada komoditi padi sawah. Padahal pengaruh perubahan iklim dinyatakan oleh Kementan (2011) bersifat multidimensional mulai dari sumberdaya, infrastrukur pertanian, sistem produksi pertanian, aspek ketahanan dan kemandirian pangan, serta kesejahteraan masyarakat petani pada umumnya. Artinya petani komoditi non-padi yang dalam penelitian ini dispesifikkan pada petani dataran tinggi layak dikaji untuk mengetahui tingkat kerentanannya terhadap perubahan iklim sehingga bisa memperkaya dan melengkapi dasar kebijakan bagi upaya menghadapi tantangan dan peluang perubahan iklim yang lebih komprehensif.

Penelitian ini melihat bagaimana petani melakukan strategi adaptasi dalam menghadapi perbahan iklim dengan pembahasan yang dititikberatkan pada petani dataran tinggi. Selama ini dataran tinggi banyak dimaknai sebagai wilayah yang tertinggal atau dalam terminologi $\mathrm{Li}$ (2002) dataran tinggi disebut sebagai daerah pedalaman yang terbentuk sebagai wilayah yang tersisih melalui perjalanan politik, ekonomi, dan sosial dengan daerah dataran yang rendah yang telah lama dan terus berlangsung. Tjondronegoro (2008) menjelaskan bahwa dataran tinggi disebut sering disebut sebagai tanah marjinal yang merupakan suatu hasil keterpaksaan, penduduk yang membangun masyarakat disana relatif baru dan sering lebih mobile. Disebutkan pula bahwa pelapisan sosial penduduk di tanah marjinal tidak semantap daerah persawahan dan tingkat kesenian tidak terlalu unggul. Pendapat yang serupa telah dipaparkan sebelumnya oleh Hefner (1999) yang menyebutkan bahwa masyarakat pegunungan (dataran tinggi) memiliki struktur longgar, serba kabur pelapisan sosialnya, dimana ikatan-ikatan antar individu sangat longgar.

Yuliati (2011) menyatakan bahwa pertanian dataran tinggi tidak memiliki daya tahan ekologis yang mantap seperti yang terjadi pada sistem pertanian sawah. Sawah merupakan sistem pertanian yang sungguh-sunguh berkesinambungan, memiliki kemampuan untuk dikelola secara intensif dalam waktu yang tidak ditentukan. Sebaliknya pertanian di dataran tinggi sebagaimana dijelaskan oleh Hefner (1999) merupakan pertanian dengan sejarah krisis ekologi yang terjadi terus menerus. Kondisi ini disebabkan lahan datar atau berlereng landai dan yang relatif subur lama-kelamaan semakin habis sehingga pemanfaatan lahan semakin ke wilayah yang seharusnya diperuntukkan untuk kawasan lindung.

Kementan (2011) menyebutkan bahwa hampir semua sub sektor pertanian rentan terhadap perubahan iklim, terutama sub-sektor hortikultura yang identik dengan dataran tinggi.
Jika sub-sektornya memiliki resiko tinggi maka petani yang bersentuhan langsung dengan aktivitas pertanian menjadi golongan yang paling rentan. Oleh karenanya penelitian ini ditekankan untuk mengetahui bagaimana petani dataran tinggi melakukan adaptasi perubahan iklim dengan melakukan studi petani di Dataran Tinggi Dieng. Berdasarkan penelitian Turasih dan Adiwibowo (2012) tentang petani di Dataran Tinggi Dieng diketahui bahwa sejarah pertanian membentuk budaya di kalangan komunitas petani. Masuknya komoditas hortikultura khususnya kentang ke wilayah Dataran Tinggi Dieng pada periode tahun 1980-an merupakan bentuk adaptasi ekonomi yang menggantikan ketidakpastian penghasilan dari budidaya palawija dan tembakau.

Pertanian sebagai sumber nafkah utama di Dataran Tinggi Dieng, masih menjadi primadona dalam berbagai musim walaupun dengan pendapatan yang fluktuatif. Turasih dan Adiwibowo (2012) menyebutkan bahwa usaha tani di Dataran Tinggi Dieng memiliki resiko yang harus siap ditanggung oleh petani. Kondisi ekologi Dataran Tinggi Dieng yang semakin menurun kualitasnya, cuaca yang semakin tidak menentu, serta fluktuasi harga di pasar memberikan konsekuensi bagi petani untuk berjaga-jaga. Faktor perubahan iklim menuntut petani dataran tinggi untuk lebih kreatif dan proaktif dengan melakukan strategi yang mampu adaptif terhadap perubahan iklim.Dalam penelitian ini aktivitas petani yang berhadapan dengan kondisi alam sehingga membuat petani berhadapan dengan resiko pertanian dipahami secara spesifik sebagai bagian dari bersinggungannya aktivitas manusia dengan perubahan iklim. Resiko yang dihadapi terutama berhadapan dengan kondisi keragaman iklim yang semakin sulit diprediksi dan berpengaruh dengan sistem penghidupan petani. Kemampuan dan strategi adaptasi petani terhadap kejadian perubahan iklim menentukan tingkat resiliensi (daya tahan) mereka ketika menghadapi kondisi yang merugikan. Pemahaman mengenai kemampuan dan strategi adaptasi petani di Dataran Tinggi Dieng dapat memperkaya kebijakan perubahan iklim, khususnya di tingkat lokal dan daerah yang secara tidak langsung juga terintegrasi dengan kebijakan perubahan iklim di tingkat nasional.

Kolopaking (2012) menyebutkan bahwa peranan iklim dalam pembangunan telah berkembang sejak dekade 1970an hingga saat ini dengan pola pendekatan yang berbedabeda. Pada dekade 1970-1990 pembangunan menggunakan sistem sentralistik melalui pengembangan pusat-pusat produksi serta revolusi hijau dengan strategi penyuluhan untuk pertanian. Masa ini disebut sebagai masa dimana 'Iklim untuk Pembangunan'. Pada periode 1990-1998 pembangunan terfokus pada beberapa aspek yaitu pembangunan dan konservasi, pengembangan wilayah, pendekatan kelompok sasaran, pengembangan pedesaan terpadu, inisiatif LSM, pengembangan masyarakat dan sektor privat serta Payment for Environmental Services (PES). Pendekatan tersebut berkembang pada awal tahun 2000-an dimana pembangunan dan konservasi dilakukan berbasis masyarakat serta muncul strategi pembangunan melalui Reward Upland Poor of Asia for the Environment Services They Provide (RUPES). Pada masa tersebut iklim dalam pembangunan dan konservasi/ pengelolaan lingkungan hidup telah mulai dilakukan bersama komunitas. Perkembangannya kemudian dari periode 2000 -an hingga sekarang adalah telah muncul dukungan stakeholder terhadap inisiatif komunitas untuk mitigasi dan adaptasi perubahan iklim. Iklim dipahami sebagai resiko dan peluang untuk komunitas melakukan inisiasi pembangunan daerah rendah emisi. Oleh karenanya pengorganisasian strategi adaptasi petani dataran tinggi dalam menghadapi perubahan iklim boleh menjadi sumbangan untuk penguatan kelembagaan 
kebijakan adapatasi perubahan iklim di tingkat daerah dan juga terintegrasi dengan kebijakan di tingkat nasional.

Menurut Eriksen dan Selboe (2012) petani dataran tinggi melakukan adaptasi terhadap terjadinya keragaman iklim melalui bentuk-bentuk kolaborasi dengan membangun relasi sosial. Petani secara aktif membangun pola relasi informal dalam melakukan adaptasi seperti dalam aktifitas melakukan ekstensifikasi maupun intensifikasi pertanian. Relasi-relasi informal yang muncul pada komunitas petani dilakukan dalam rangka mengamankan produksi pertanian sekaligus menjaga kualitas kehidupan. Relasi informal dalam mengelola terjadinya keragaman iklim ini terus dijaga meskipun terjadi perubahan skala produksi ke arah yang lebih besar, meningkatnya formalisasi, maupun diversifikasi ekonomi.

Berdasarkan IPCC (2007) aksi-aksi adaptasi menghadapi perubahan iklim memiliki penggerak yang bermacam macam mulai dari pembangunan ekonomi, pengurangan kemiskinan, serta hal-hal yang berkaitan dengan pembangunan internasional, sektoral, daerah serta perencanaan pembangunan melalui inisiatif lokal. Hasil penelitian IPCC (2007) menyarankan bahwa keuntungan yang lebih tinggi dapat dicapai jika adaptasi dilakukan secara terencana dengan mempertimbangkan kapasitas adaptif masyarakat yang sifatnya dinamis. Kapasitas adaptif sifatnya dinamis dan dipengaruhi oleh basis produksi masyarakat yang meliputi modal alam (natural asset) dan modal buatan manusia (man-made capital assets) yang meliputi jaringan sosial, modal manusia dan kelembagaan, pemerintahan, pendapatan nasional, pendapatan, dan teknologi. Selain itu dipengaruhi juga oleh beragam tekanan baik iklim itu sendiri maupun tekanan non-iklim seperti kebijakan pembangunan. Hal ini kemudian ditekankan oleh Boer dan Kolopaking (2010) dalam Kolopaking (2011) dimana adaptasi terhadap perubahan iklim merupakan bentuk adaptasi yang direncanakan (planned adaptation). Adaptasi tersebut dilakukan sebagai upaya untuk menanggapi dampak perubahan iklim khususnya keragaman iklim yang semakin sukar diprediksi dan berdampak bagi sistem kehidupan baik aspek alam (nature) berupa sumber makanan, ekosistem, kesehatan, dan sebagainya maupun aspek manusia.

Melihat konteks petani dataran tinggi dengan berdasar pada pengertian adaptasi yang telah disebutkan, maka penelitian ini diarahkan untuk mengetahui dan memahami bagaimana strategi adaptasi perubahan iklim dilakukan oleh petani dataran tinggi. Pemahaman mengenai pertanian dataran tinggi yang kurang stabil dibandingkan pertanian dataran rendah menurut Yuliati (2011) serta kerusakan ekologi dataran tinggi yang berkelanjutan menurut Hefner (1999) menjadi pemicu kerentanan bagi golongan petani dataran tinggi. Kerentanan tersebut semakin diperparah dengan kejadian keragaman iklim. Kerentanan terhadap perubahan iklim sesuai pengertian IPCC (2007) merupakan derajat dimana suatu sistem tidak dapat bertahan karena efek perubahan iklim termasuk karena kejadian iklim ekstrim dan keragaman iklim. Kerentanan terhadap perubahan iklim dipengaruhi oleh kapasitas adaptasi, sensitifitas, dan keterpaparan terhadap perubahan iklim.

Berdasarkan fakta tersebut, untuk menjelaskan dan memahami strategi adaptasi perubahan iklim yang dilakukan oleh petani dataran tinggi maka penelitian ini menjawab pertanyaan bagaimana petani dataran tinggi melakukan strategi adaptasi untuk menghadapi perubahan iklim?

Berdasarkan rumusan masalah yang telah dijabarkan, tujuan penelitian ini adalah untuk Menjelaskan dan memahami bagaimana petani dataran tinggi melakukan strategi adaptasi dalam menghadapi perubahan iklim.

\section{METODE PENELITIAN}

Penelitian ini merupakan penelitian kualitatif yang didukung oleh data kuantitatif berdasarkan paradigma konstruktivisme. Pendekatan kualitatif yang dipilih berkaitan dengan paradigma konstruktivistik mengandalkan grounded research dan fenomenologi untuk melihat interpretasi-konstruktif dari tineliti mengenai pemaknaan atas fenomena yang terjadi. Paradigma konstruktivistik bertujuan untuk memahami dan merekonstruksi berbagai konstruksi yang sebelumnya dipegang orang (termasuk peneliti), yang berusaha ke arah konsensus namun masih terbuka bagi interpretasi baru seiring dengan perkembangan informasi.

Penelitian dilakukan di wilayah Dataran Tinggi Dieng di Kecamatan Batur, Kabupaten Banjarnegara. Penelitian menganalisa wilayah Dataran Tinggi Dieng sebagai satu kawasan yang terdiri dari 8 Desa yaitu Desa Batur, Desa Sumberejo, Desa Pekasiran, Desa Kepakisan, Desa Karang Tengah, Desa Bakal, Desa Pesurenan, dan Desa Dieng Kulon. Kemudian untuk menganalisa kondisi spesifik desa diambil studi kasus di Desa Batur. Penelitian juga dilakukan di berbagai SKPD (Satuan Kerja Perangkat Daerah) di Kabupaten Banjarnegara yang meliputi Bappeda, Dinas Pertanian dan Peternakan, Dinas Kehutanan dan Perkebunan, BMKG, dan Badan Penanggulangan Bencana Daerah. Penelitian dilakukan pada bulan November-Desember tahun 2014.

Jenis data dalam penelitian ini terdiri dari data primer dan data sekunder. Data primer berasal dari hasil wawancara dan observasi langsung, sedangkan data sekunder berasal dari literatur, dokumen, film, dan data-data statistik yang berhubungan dengan lokasi penelitian. Data penelitian berupa data kualitatif dan data kuantitatif. Data kualitatif bersumber dari hasil wawancara, literatur, dokumen, film, dan sumber yang relevan. Sedangkan data kuantitatif utama dalam penelitian bersumber dari dari data statistik berupa data Kecamatan Batur Dalam Angka Periode Tahun 19902014. Data kuantitatif lainnya diperoleh dari sumber literatur pendukung yang sesuai dengan konteks penelitian. Analisis data mengikuti tahapan analisis yang digagas oleh Huberman dan Miles (1997) dimana analisis data menggunakan model interaktif dan penyajian datanya bersifat sekuensial dan interaktif. Analisis data meliputi tiga subproses yang saling terkait yaitu reduksi data, penyajian data, dan pengambilan keputusan/verifikasi.

\section{HASIL DAN PEMBAHASAN}

\section{Perubahan Iklim di Dataran Tinggi Dieng}

Perkembangan wilayah Dataran Tinggi Dieng kentara terlihat dari proses perubahan kondisi lansekap di kawasan tersebut pada era pra dan pasca introduksi tanaman kentang. Perubahan yang lebih dapat teridentifikasi secara langsung adalah aspekaspek yang berhubungan dengan pemanfaatan lahan seperti kondisi hutan, sumber daya air, dan kondisi lahan pertanian. Berdasarkan data dari Pemerintah Kabupaten Banjarnegara (2012) diketahui bahwa perkembangan Dataran Tinggi Dieng menunjukkan fakta kerusakan lingkungan yang semakin mencemaskan. Kerusakan ini semakin diperparah dengan kondisi iklim yang tidak menentu terutama kondisi curah hujan yang menyebabkan intensitas kejadian longsor menjadi semakin tinggi.

Kejadian longsor yang semakin bertambah intensitasnya dalam kurun waktu 40 tahun terakhir selain dipengaruhi oleh 
kondisi luas tutupan lahan hutan yang semakin berkurang juga karena jumlah hari hujan yang semakin bertambah pada bulan basah. Sejak tahun 1990 bulan basah dengan jumlah hari hujan yang lebih banyak terjadi pada bulan Januari, Februari, Maret, April, Oktober, November, dan Desember. Bulan kering terjadi antara Mei, Juni, Juli, Agustus, dan September dengan jumlah hari hujan yang semakin sedikit. Berdasarkan Gambar 10, diketahui bahwa dalam kurun waktu tahun 1990 - 2000 jumlah hari hujan di tahun 2000an meningkat di bulan basah dan berkurang di pada saat bulan kering. Kondisi ini berdasarkan Efendi, Sunyoko, dan Sulistya (2012) menyebabkan kecenderungan meningkatnya resiko kejadian longsor di musim penghujan dan kekeringan di musim kemarau. Resiko tersebut telah terjadi di Dataran Tinggi Dieng. Pada musim penghujan, kejadian longsor semakin banyak terjadi di lahan-lahan pertanian yang miring dan memunculkan resiko ke wilayah-wilayah yang berada lebih jauh di bawahnya. Sebaliknya, pada musim kemarau masyarakat yang bermatapencaharian sebagai petani harus mengeluarkan biaya penyedotan air telaga atau sumber air lain untuk menyiram lahan pertaniannya.

WWF (2007) menyatakan bahwa perubahan distribusi curah hujan menyebabkan potensi bencana alam yang dipicu oleh curah hujan menjadi semakin tinggi seperti banjir, longsor, peluapan sungai, dan penyebaran vektor penyakit. Sebaliknya pada kondisi curah hujan yang mengecil potensi bencananya berupa kekeringan, gagal panen, kekurangan air bersih, dan berbagai permasalahan sosial yang mungkin timbul. Persoalan yang dihadapi di Dataran Tinggi Dieng serupa dengan gambaran tersebut dimana jumlah curah hujan memiliki tren menurun dari tahun 1990 hingga 2014 (Lampiran 1) namun jumlah hari hujan di bulan basah semakin meningkat (Lampiran 2).

Indikator perubahan iklim dari aspek peningkatan temperatur tidak terlalu kentara di Dataran Tinggi Dieng karena kondisi iklimnya yang masih sejuk. Berdasarkan data BMKG stasuin Kalilunjar-Banjarnegara tahun 2009-2014 diketahui bahwa suhu rata-rata maksimal sekitar 28,5 derajat celcius dan suhu rata-rata minimalnya sekitar 20,7 derajat celcius. Pada musim kemarau sekitar bulan Juli-Agustus, suhu minimum bisa mencapai 0 derajat. Kondisi perubahan yang lebih kentara yang adalah kondisi jumlah hari hujan dan curah hujan di Dataran Tinggi Dieng menunjukkan indikasi terjadinya perubahan iklim mikro di tingkat wilayah. Hal yang paling dapat ditandai adalah kejadian iklim ekstrem yang lebih sering terjadi sejak tahun 2007 yaitu hujan yang lebih deras dan musim kemarau yang lebih kering. Kondisi tersebut diperburuk dengan minimnya luas tutupan lahan yang tersisa di wilayah Dataran Tinggi Dieng sebagai area tangkapan air. Kawasan hutan di Dataran Tinggi Dieng berangsur habis dikonversi menjadi kebun kentang. Kementrian Lingkungan Hidup mencatat, dari luas Dataran Tinggi Dieng 619.846 ha, hutan yang tersisa tinggal 20,1 persen padahal idealnya 30 persen (Kompas 03 Juni 2011). kondisi tutupan lahan yang kurang dari 30 persen tersebut masih berlangsung hingga penelitian ini dilaksanakan (tahun 2014). Berdasarkan penuturan dari narasumber penelitian dari Dinas Kehutanan dan Perkebunan, bahwa kondisi tutupan lahan kurang dari 30 persen menyalahi amanat UU No. 41 Tahun 1999 tentang Kehutanan. Berkurangnya tutupan lahan hutan tersebut diakibatkan konversi lahan hutan ke lahan pertanian kentang.

\section{Pengetahuan Petani Tentang Perubahan Iklim}

Perubahan iklim di Dataran Tinggi Dieng dipahami oleh masyarakat berdasarkan fenomena lokal yang terjadi.
Secara umum jika dibandingkan dengan wilayah lainnya di Kabupaten Banjarnegara, Dataran Tinggi Dieng merupakan wilayah dengan suhu dingin sehingga gejala perubahan iklim dari peningkatan suhu tidak terlalu dirasakan oleh masyarakat. Namun demikian, mereka mengakui bahwa situasi saat ini di Dataran Tinggi Dieng relatif lebih hangat dibanding ketika tahun 1990-an. Diungkapkan oleh salah seorang narasumber penelitian bahwa saat ini ia tidak perlu menggunakan jaket yang terlalu tebal atau bahkan di saat tertentu ketika suhu terasa hangat ia tidak perlu mengenakan jaket.

\begin{abstract}
"Nggih seniki sampun lumayan anget Mbak, timbang mbiyen pas kulo tasih enem, jan nek asrep nggih bener-bener asrep. Nek seniki rasane biasa wae. Mbiyen sering nganggo sarung, seniki ngganggo tapi mboten ndina-ndina." (AB, 54 tahun)
\end{abstract}

Artinya

(Sekarang sudah lumayan hangat Mbak, dibanding dulu ketika saya masih muda, kalau dingin benarbenar dingin. Kalau sekarang rasanya biasa saja. Dulu sering pakai sarung, sekarang pakai tetapi tidak seharian).

Hal yang sama juga dikatakan oleh petugas dari Dinas Pertanian dan Peternakan Kabupaten Banjarnegara yang bertugas di Dataran Tinggi Dieng, Kecamatan Batur.

"Kondisi Dieng sekarang sudah berbeda, selama 14 tahun bertugas di Banjarnegara, dulu ketika bertugas ke Dieng harus pakai jaket, namun sekarang merasa tidak apa-apa jika memakau baju biasa. Suhu sudah menjadi lebih hangat. Dulu nggak pernah dirasakan suhu sampai tiga puluh derajat di Dieng, tapi sekarang bisa terasa apalagi ketika kondisi ramai seperti saat musim liburan dan musim wisata $\mathrm{DCF}^{1}$." (SH, 54 tahun)

Indikasi menghangatnya suhu di Dataran Tinggi Dieng juga terjadi dengan ditandainya kemunculan hewan cicak yang saat ini menjadi lebih banyak. Meskipun diduga bahwa cicak bisa berasal dari daerah yang lebih hangat misalnya ada orang yang pulang dari kota (suhu hangat) dengan membawa kardus atau tempat yang di dalamnya bisa jadi terdapat cicak. Kenyataan bahwa cicak dapat hidup di wilayah dingin menjadi satu tanda bahwa wilayah tersebut sudah semakin hangat. Indikasi lain bahwa suhu sudah semakin menghangat adalah dilihat dari pertumbuhan tanaman. Semakin hangat suhu lingkungan maka tanaman akan tumbuh semakin tinggi. Hal tersebut juga terjadi pada tanaman kentang yang rata-rata saat ini tumbuh semakin tinggi.

Petani memaknai perubahan iklim sebagai sebuah kondisi iklim yang sangat mengancam aktivitas pertanian. Petani mengidentifikasi lima fenomena iklim utama yang terjadi dan berkait dengan pertanian mereka yaitu: (1) curah hujan yang semakin ekstrem pada musimnya, (2) situasi kekeringan yang melanda pertanian, (3) musim angin ribut, (4) kondisi suhu ekstrem pada Bulan Juli atau Agustus ketika muncul embun upas atau titik salju yang menjadikan tanaman muda menjadi layu dan mati, serta yang paling meresahkan adalah (5) kondisi iklim yang semakin sukar diprediksi.

Pada saat musim hujan, diakui bahwa curah hujan menjadi lebih deras yang akibatnya kejadian erosi di lahan pertanian menjadi semakin tinggi. Kondisi lahan pertanian yang miring dan tidak memiliki kontur terasering menjadi penyebab tanah semakin mudah terbawa aliran air hujan. Pola penanaman di lahan tanpa teras memicu potensi erosi yang tinggi karena

1 Dieng Culture Festival 
lapisan tanah bagian atas akan terbawa air hujan yang memunculkan sedimentasi pada saluran-saluran air. Tidak hanya di lahan pertanian, namun hampir seluruh wilayah di Dataran Tinggi Dieng termasuk Desa Batur rawan longsor pada saat musim hujan. Musim hujan merupakan musim yang paling ditakuti petani karena resiko kegagalan lebih tinggi pada musim ini dimana tanaman kentang lebih banyak layu. Musim hujan merupakan musim yang sulit bagi petani karena biaya produksi cenderung naik namun produksi justru turun.

Pada periode 2010/2011 sepanjang tahun terjadi hujan dan petani banyak dirugikan pada saat kondisi itu. Hama menjadi tinggi pada saat musim hujan karena biasanya pestisida tidak mempan digunakan pada musim tersebut. Hama jenis litoptera yang dikenal petani dengan istilah tekle atau folio saat ini tidak hanya menyerang batang tetapi juga sudah menyerang daun. Tanaman kemudian menjadi layu dan mati. Pada tahun 2012 muncul hama kutu kebul. Musim hujan menyebabkan intensitas kemunculan hama menjadi tinggi.

Pada tahun 1958 pernah terjadi kemarau panjang hingga 9 bulan, kemudian sekitar tahun 1964 kemarau panjang terjadi hingga 6 bulan. Awal musim kemarau merupakan musim yang sangat sulit bagi petani karena merupakan musim transisi dari penghujan ke kemarau. Banyak petani yang tidak menanam pada awal kemarau karena takut gagal. Akibat kondisi tanah yang gembur, pada saat musim kemarau, air tanah menjadi mudah menguap dan mengakibatkan lahan pertanian menjadi rawan kekeringan. Kondisi sumber air untuk pertanian di Dataran Tinggi Dieng pada musim kemarau debitnya menjadi lebih kecil. Salah satu sumber air yang dimanfaatkan untuk pertanian pada saat musim kemarau adalah Telaga Merdada yang diambil dengan cara menyedotnya menggunakan mesin genset. Efeknya, jika air telaga disedot dalam jumlah besar maka debitnya akan menjadi semakin kecil. Air merupakan hal yang krusial diperlukan dalam pertanian kentang karena kondisi lahan pertanian kentang tidak dapat menyimpan air tanah. Musim kemarau merupakan musim yang relatif sulit bagi petani apabila tidak ada sumber air. Pada musim ini, petani yang mengolah lahan jauh dari sumber air hanya bisa menanam satu tahun sekali.

Pada bulan Juli atau Agustus muncul embun upas di Dataran Tinggi Dieng. Meskipun telah disadari oleh petani bahwa kejadian ini rutin terjadi, namun petani tetap khawatir. Pada saat itu suhu berada di titik kritis mencapai suhu nol dan bahkan minus sehingga menyebabkan munculnya frozz. Suhu terendah yang terjadi pada saat titik kritis bisa mencapai $-8^{0}$ Celcius dan menyebabkan tanaman kentang layu dan busuk dan petani beresiko gagal panen. Kekhawatiran petani juga disebabkan oleh munculnya angin ribut. Pada tahun 2011 terjadi serangan angin ribut yang merusak tanaman kentang. Angin ribut ini menjadi perkara besar bagi petani karena berdasarkan perhitungan terjadi setiap lima tahun sekali. Jika sebelumnya terjadi di tahun 2011 maka ke depan diprediksi tepat akan terjadi pada akhir tahun 2015 atau awal 2016. Pada musim angin tegakan tanaman rusak dan tanaman yang baru tumbuh habis tersapu angin.

Selain empat kondisi yang telah dijelaskan, hal yang paling meresahkan bagi petani adalah prediksi musim yang semakin sulit ditebak. Petani menghadapi musim yang membingungkan, menebak terjadi musim hujan namun kenyataannya kemarau dan demikian juga sebaliknya. Dulu petani masih menggunakan pranata mangsa untuk menandai musim tanam, namun hal tersebut tidak lagi akurat apalagi semenjak melewati sekitar tahun 2007. Pranata mangsa saat ini tidak lagi sama dengan perhitungan petani dan juga tidak sama dengan data yang dirilis oleh Badan Meteorologi,
Klimatologi, dan Geofisika (BMKG). Sulitnya prediksi musim saat ini menyebabkan petani sangat membutuhkan informasi cuaca dan iklim yang sifatnya harian karena penting untuk menentukan musim tanam. Perhitungan musim tanam tersebut sangat berkaitan dengan biaya produksi yang harus dikeluarkan oleh petani. Sebelum tahun 2007 musim masih dapat diprediksi namun memasuki tahun 2008 relatif lebih sulit dan sering meleset dari prakiraan.

\begin{abstract}
"Iklim sudah bergeser jauh. Mangsa kanem-kapitu yang dulu terjadi pada Bulan November-Desember merupakan musim yang paling enteng dan cocok untuk menanam. Namun saat ini waktu tersebut menjadi musim yang paling berat. Tahun 2010 kondisi lebih kering jadi tidak terlalu bermasalah untuk petani. Pada tahun 2013 sampai 2014 kondisi hujan lebih banyak sehingga terasa lebih berat." (DD, 34 tahun)
\end{abstract}

Banyak petani bangkrut karena kondisi iklim yang tidak menentu. Pada tahun 1983 perbandingan penanaman 1 keranjang bisa panen hingga 10 keranjang. Sejak tahun 2000an, 1 keranjang benih hanya memberikan 7-8 keranjang panen ketika musimnya stabil dan pada musim penghujan hanya sekitar 5 keranjang. Hal tersebut menjadi cerminan fenomena bahwa perubahan iklim menjadi sebuah tantangan yang harus dihadapi oleh petani karena berkaitan langsung dengan setiap kegiatan pertanian dan mempengaruhi kondisi kehidupan petani.

\section{Lokalitas Dampak Perubahan iklim}

Perubahan iklim merupakan fenomena global namun dampaknya bersifat lokal dan regional serta mempengaruhi komunitas dalam intensitas yang berbeda. Bagi petani dataran tinggi, kondisi iklim sangat penting terutama terkait dengan pencahayaan sinar matahari, suhu, serta ketersediaan air. Identifikasi dampak perubahan iklim yang dirasakan oleh petani di Dataran Tinggi Dieng didasarkan pada berbagai perubahan yang terjadi di tingkat wilayah serta penuturan yang disampaikan oleh petani.

\section{Dampak Fisik dan Ekologi}

Dampak perubahan iklim secara fisik dan ekologis di Dataran Dieng berkaitan dengan praktek pertanian hortikultur sayuran terutama kentang yang bersifat monokultur di wilayah tersebut. Tuntutan kondisi lahan pertanian kentang yang harus terbuka dan tidak terganggu naungan pohon menyebabkan kondisi kawasan Dataran Tinggi minim tutupan lahan. Selain itu keperluan pertanian kentang adalah kontur tanah miring yang dibuat searah dengan kemiringan lereng dan penggunaan dosis pupuk yang tinggi.
"Secara kasat mata memang tidak banyak yang kelihatan berubah kecuali tutupan lahan yang semakin berkurang. Namun perlakukan terhadap lahan sangat mempengaruhi kondisi lingkungan saat ini. Saat ini pupuk N sudah terlalu tinggi kadar penggunaannya. Sumber N dapat berasal dari pupuk organik mapun anorganik sepeti urea dan ZA. Ciri-ciri tingginya kandungan $\mathrm{N}$ ini dapat dilihat di bagian kanan dan kiri screen pembenihan kentang dimana lumut sudah banyak dijumpai."(SH, 50 tahun)

Kondisi fisik dan ekologi pada saat musim ekstrem menjadi keluhan tersendiri bagi masyarakat di Dataran Tinggi Dieng. 
Dampak perubahan iklim dalam aspek fisik dan ekologi lebih ke arah dampak negatif dan dapat berujung bencana. Pada saat musim hujan banyak terjadi longsor dan pada saat musim kemarau bisa terjadi kebakaran hutan yang ada di sekitar Dataran Tinggi Dieng serta berkurangnya debit air untuk pertanian. Diungkapkan oleh narasumber juga bahwa pada musim hujan intensitas kejadian bencana gas beracun menjadi lebih tinggi.

Kejadian iklim yang berkaitan dengan curah hujan serta angin ribut memberikan konsekuensi kerusakan dan peningkatan potensi bencana alam. Dari segi infrastruktur wilayah, perubahan iklim terutama karena curah hujan yang ektrem menyebabkan kerusakan jalan aspal di wilayah Dataran Tinggi Dieng berlubang. Di Desa Batur, jalanan rusak terdapat di area Pasar Batur serta jalan-jalan menuju dusun-dusun yang jauh dari pusat pemerintahan. Kerusakan tersebut diperparah juga akibat jalan dilintasi kendaraan dengan muatan yang berat. Pada musim hujan, dampak curah hujan yang tinggi akan tampak di sepanjang jalan raya yang berdekatan dengan area pertanian. Jalan raya beraspal yang posisinya lebih landai dibanding lahan pertanian banyak tertutup tanah yang dibawa oleh aliran air hujan. Pada kondisi ektrem tertentu, curah hujan yang tinggi menyebabkan longsor yang tidak hanya berdampak bagi kondisi lahan pertanian tetapi juga mengancam keamanan rumah-rumah penduduk yang posisinya dekat dengan lereng dan aliran sungai. Angin ribut menyebabkan kerusakan pada bangunan rumah, pohon tumbang, dan rusaknya tanaman pertanian.

Pada saat musim kemarau, meskipun dikatakan oleh narasumber bahwa sumber air relatif masih ada dan mencukupi untuk pertanian di Dataran Tinggi Dieng namun fenomena kekeringan tidak dapat dipungkiri menjadi persoalan tersendiri. Semua desa di Dataran Tinggi Dieng rawan dengan kondisi kekeringan. Pertanian mengandalkan air telaga untuk dimanfaatkan pada musim kemarau, petani memasang pompa air yang dioperasikan dari pagi hingga sore hari (jam 7 pagi hingga 4 sore) dan bahkan ada yang dipasang selama 24 jam. Dampak yang ditimbulkan dari penyedotan air secara serempak ini adalah debit air telaga menjadi semakin cepat berkurang. Petani merasa khawatir apabila air telaga disedot secara terus menerus pada musim kemarau dan musim hujan terlambat datang maka cadangan air untuk pertanian akan habis.

Musim kemarau juga menjadi musim yang rentan terhadap kejadian kebakaran hutan. Kawasan Dataran Tinggi Dieng dikelilingi oleh hutan lindung yang rentan kebakaran pada saat musim kemarau. Kejadian kebakaran hutan yang cukup luas terjadi pada Bulan Juli tahun 2014 dimulai dari area Kabupaten Batang dan merambat ke Kabupaten Banjarnegara di Kecamatan Batur. Kebakaran tersebut dimungkinan oleh gesekan ranting kayu maupun akibat keringnya tanaman yang disebabkan oleh serangan embun upas. Dituturkan oleh masyarakat bahwa sejarah kekeringan dan kebakaran hutan dulu tidak pernah terjadi bahkan ketika kejadian kemarau panjang hingga 9 bulan di tahun 1958. Ketika pertanian intensif kentang dan hortikultur sayuran digalakkan, pada saat kemarau mudah sekali terjadi kekeringan dan kebakaran.

\section{Dampak Ekonomi}

Pada saat menghadapi musim kemarau khususnya dengan kondisi kekeringan yang terjadi, petani harus menambah biaya produksi pertanian untuk memperoleh air yang cukup bagi penyiraman tanaman. Petani tidak memiliki pilihan lain selain memompa air. Setiap hari petani memerlukan 5-20 liter bahan bakar premium untuk mengoperasikan mesin pompa air dan mengalirkannya dari telaga ke lahan pertanian. Jarak antara telaga sember air dengan lahan pertanian berkisar mulai dari 400 meter hingga $3 \mathrm{~km}$, semakin jauh jaraknya maka biaya yang dikeluarkan semakin besar. Satu hari petani biasanya hanya mampu menyiram hingga 0,5 ha lahan, apabila lahannya lebih luas maka diperlukan waktu lebih lama dan jumlah biaya tenaga kerja yang lebih besar. Kondisi tersebut berlangsung hingga 2-3 bulan sampai puncak musim kemarau. Bagi petani yang mengolah lahan ertanian sangat jauh dari sumber air akhirnya ada yang memilih hanya menanam satu kali per tahun karena tidak memiliki modal yang cukup.

\section{"Menawi mangsa terang kulo kedah tumbas bensin limolas liter nggo mompa banyu. Limolas liter dinggo nyiram lahan setengah hektar." (KS, 45 tahun)}

Artinya

(Apabila musim kemarau saya harus membeli bensin lima belas liter untuk memompa air. Lima belas liter digunakan untuk menyiram lahan setengah hektar).

Musim kemarau bukan menjadi titik kekhawatiran petani tentang biaya produksi. Petani perlu mengeluarkan biaya yang lebih besar pada musim hujan. Pada musim penghujan, petani perlu membeli pestisida dan obat-obatan pertanian sehingga biaya semakin membengkak. Pada musim hujan, petani juga perlu menambah tenaga kerja untuk pertanian guna meminimalisir gagal kerja. Hal ini karena musim hujan menyebabkan pekerja lebih sering beristirahat ketika hujan turun. Oleh karenanya jumlah tenaga perlu ditambah guna memperoleh hasil kerja yang diharapkan dengan jangka waktu yang telah ditentukan. Tenaga kerja di pertanian kentang dibayar Rp 25.000 selama 5 jam kerja dari jam 08.00 pagi hingga jam 14.00 siang jika tidak disediakan makanan oleh pemiliki lahan. Sedangkan jika pekerja mendapatkan makanan (dikirim makanan ke kebun) maka upah yang diterima hanya Rp 20.000 dengan jumlah jam kerja yang sama. Perbedaan yang dihadapi oleh petani untuk musim hujan dan musim kemarau terkait tenaga kerja adalah pada musim kemarau petani harus menanggung biaya tenaga kerja untuk penyiraman tanaman karena kurangnya ketersediaan air. Sedangkan di musim penghujan, petani menghadapi mahalnya biaya perawatan untuk pembelian pestisida. namun bagi petani, musim kemarau lebih menguntungkan dibanding musim hujan.

Dari sisi pendapatan diketahui bahwa fluktuasi harga kentang tidak selalu mengalami perubahan yang signifikan. Namun demikian kondisi iklim yang ekstrem memberikan konsekuensi pengeluaran pertanian yang lebih besar yaitu pada musim hujan untuk membeli pestisida dan pada musim kemarau untuk melakukan penyedotan air. Musim hujan cenderung berdampak negatif bagi penghasilan petani, sebaliknya pada musim kemarau petani dapat lebih untung. Pada saat pendapatan tinggi di musim kemarau petani dapat mengalokasikan pendapatannya dengan lebih leluasa baik untuk pengeluaran non pangan dan investasi. Ketika pendapatan menurun, di tingkat rumah tangga petani harus mengurangi konsumsi non pangan dan tidak ada investasi. Pada saat pendapatan turun beberapa kasus di rumah tangga hingga sampai menjual atau menyewakan aset utama berupa lahan pertanian, meningkatkan hutang, dan menurunkan konsumsi.

\section{Dampak Sosial}

Sulitnya prediksi musim menjadi keniscayaan bagi petani 
untuk harus siap dan sedia menghadapi ketidakstabilan kondisi pertanian. Perubahan kondisi fisik pertanian menyebabkan berbagai perubahan dari aspek sosial. Sebelum tahun 2000-an tenaga kerja pertanian di Desa Batur kebanyakan berasal dari luar desa dan luar kecamatan. Seiring dengan perkembangan waktu dan pilihan bekerja di luar sektor pertanian tenaga kerja luar desa tersebut semakin susah didapatkan. Menghadapi kondisi sulitnya memperoleh tenaga kerja di tengah tuntutan keperluan tenaga kerja di musim-musim ekstrem, petani saling bekerjasama untuk menentukan giliran penggunaan tenaga kerja dengan sistem menunggu selesainya pekerjaan di lahan petani lain. Hal tersebut meningkatkan intensitas komunikasi antar petani yang mengolah lahan.

Kondisi iklim yang tidak menentu menimbulkan kesadaran bagi petani terutama pada golongan muda untuk perlu memiliki wadah bersama guna membahas persoalan pertanian. Terdapat beberapa perkumpulan petani khususnya pada golongan muda diantaranya Asosiasi Penangkar Benih Kentang dan Komunitas Petani Kentang Dieng. Asosisasi Penangkar Benih Kentang anggotanya terdiri dari perkumpulan kelompok tani sejumlah 40 kelompok di Dataran Tinggi Dieng. Asosiasi penangkar benih kentang lahir sejak tahun 2009 sebagai wadah untuk menampung penangkar benih dan dapat mensertifikatkannya. Spesifikasi kegiatan asosiasi adalah dalam kegiatan pembenihan. Saat ini ada 17 orang penangkar yang berasal dari kelompok tani maupun perorangan. Komunitas Petani Kentang Dieng (KPKD) berbentuk komunitas dalam jejaring sosial facebook yang terbentuk sejak tahun 2013. karena aktif di jejaring sosial facebook maka komunitas ini mengadakan pertemuan (kopi darat) setiap satu bulan sekali pada hari jumat legi selepas solat jumat. Komunitas memiliki ketua dan administrator yang mengurus facebook. Kegiatan kopi darat biasanya dihadiri sekitar 30 orang meliputi seluruh petani di Dataran Tinggi Dieng. Komunitas ini 95\% diikuti oleh anak muda yang rata-rata bisa lebih kritis. Komunitas ini menjadi wadah untuk menyaring berbagai informasi sekaligus menjadi sarana untuk mengintorduksikan teknologi.

Munculnya kelompok dan komunitas yang memiliki perhatian terhadap perubahan kondisi iklim merupakan peluang bagi upaya adaptasi supaya petani lebih resisten terhadap perubahan iklim. Namun demikian perkembangan kelompok-kelompok tersebut perlu diperhatikan dengan lebih mendalam karena anggota kelompok yang tergabung rata-rata adalah petani yang memiliki pendidikan tinggi dan terdedah media sosial. Bagi petani golongan menengah dan tua yang tidak terlalu paham dengan media sosial, perkumpulan terbatas pada kelompok tani. Secara umum terlihat bahwa perkumpulan-perkumpulan yang ada di masyarakat petani di Dataran Tinggi Dieng dapat menjadi sarana yang efektif bagi proses pertukaran informasi di antara petani. Hanya saja jangkauan perkumpulan yang ada baik kelompok tani, asosiasi benih, maupun komunitas petani kentang lebih mengarah pada petani yang menguasai lahan (baik petani pemilik maupun penggarap). Artinya kelompok petani yang tidak menguasai lahan atau buruh tani masih tersisih darielum mau masuk dalam perkumpulan yang ada. Hal ini tidak terjadi begitu saja namun bagi mereka yang menjadi buruh tani lebih sibuk untuk mencari sumber penghidupan dibanding menghabiskan waktu untuk berkumpul.

\section{Kerentanan Petani terhadap Perubahan Iklim}

Kerentanan petani terhadap perubahan iklim dalam penelitian ini terkait erat dengan kondisi penguasaan lahan di tingkat rumah tangga. Petani di Dataran Tinggi Dieng berdasarkan penguasaan lahannya terkategori menjadi petani yang tidak menguasai lahan, petani dengan penguasaan lahan antara 0,1 ha $\leq \mathrm{x} \leq 0,3$ ha, petani dengan penguasaan lahan antara 0,3 ha $\leq \mathrm{x} \leq 0,5$ ha, petani dengan penguasaan lahan antara 0,5 ha $\leq$ $\mathrm{x} \leq 1$ ha, dan petani dengan penguasaan lahan $\geq 1$ ha. Kondisi penguasaan lahan tersebut dihubingkan dengan representasi lima modal utama yang dapat diakses oleh rumah tangga petani sesuai dengan penguasaan lahan pertaniannya dengan merujuk livelihood framework Chambers dan Conway (1991). Modal yang dimaksud meliputi modal manusia, modal sosial, modal fisik, modal finansial, dan modal sumberdaya alam.

Modal manusia yang dimaksud meliputi kapasitas pengetahuan dan keterampilan petani dalam melakukan praktek-praktek pertanian sekaligus tingkat pendidikan yang memungkinkan mereka masuk ke sektor non pertanian. Petani di Dataran Tinggi Dieng saat ini masih didominasi oleh golongan umur tua dengan pendidikan maksimal Sekolah Dasar atau pada masanya disebut Sekolah Rakyat (SR). Pada perkembangannya karena situasi pertanian kentang yang sangat menguntungkan maka usaha tani tersebut diturunkan kepada anak-anaknya yang saat ini menjadi petani muda. Sumberdaya petani yang terdiri dari anak-anak muda tersebut tingkat pendidikannya sudah lebih tinggi minimal di Sekolah Menengah Pertama (SMP). Ada juga generasi muda yang mengenyam bangku perkuliahan S1 dan S2 yang memutuskan menjadi petani. Hal ini menjadi peluang bahwa sumberdaya manusia petani ke depan khususnya dalam pertanian hortikutura akan semakin baik.

Keterkaitan petani satu sama lain merupakan salah satu bentuk modal sosial yang dimiliki oleh petani. Keterkaitan tersebut membuka informasi bagi petani satu sama lain untuk mengetahui berbagai hal terkait pertaian. Modal sosial terbentuk karena interaksi yang terus menerus dan bahkan di beberapa kasus hingga mewujudkan perkumpulan petani maupun organisasi. Perkumpulan dilakukan secara informal untuk membicarakan perihal pertanian dalam berbagai situasi misalnya ketika bertemu secara tidak sengaja di jalan maupun saling mengunjungi satu sama lain atau disebut dengan istilah ngendong (bertamu). Perkumpulan tidak hanya terwujud secara nyata tatap muka namun juga di golongan muda muncul komunitas virtual yang membahas tentang pertanian kentang, komunitas tersebut melakukan aktivitas di jejaring sosial facebook dengan nama komunitas Petani Kentang Dieng (PKD). Interaksi yang mewujud menjadi organisasi adalah tumbuhnya kelompok tani dan asosiasi penangkar benih kentang.

Menariknya modal sosial tersebut cenderung menjadi modal yang paling kuat yang dimiliki oleh petani pada berbagai tingkat penguasaan lahan. Meskipun bentuk jaringannya berbeda antara satu petani dengan petani lainnya namun setiap aktivitas petani ditentukan dari intensitas interaksi dengan orang lain. Seorang petani penguasa lahan akan lebih mudah mendapatkan pestisida jika kenal dengan pedagangnya atau pun memperoleh informasi mengenai jenis pestisida yang tepat dari tetangganya. Buruh tani akan lebih mudah memperoleh pekerjaan jika sering berinteraksi dengan buruh lainnya maupun dengan penguasa lahan karena informasi yang didapatkan semakin lancar. Artinya modal sosial dari proses interaksi petani dengan berbagai pihak menentukan proses sampainya informasi ke tangan petani.

Bagi petani selain modal manusia dan modal sosial, modal fisik juga menjadi penentu keberlangsungan kegiatan pertanian. Jenis modal fisik yang menjadi aset penduduk yang bergerak di bidang pertanian meliputi berbagai sarana produksi pertanian. Petani dengan penguasaan lahan 0,5 ha1 ha dan di atas 1 ha memiliki jenis modal fisik yang lebih beragam dan kuantitasnya lebih banyak. Biasanya petani 
tersebut memiliki mesin genset, bak pengangkut hasil panen, bahkan petani memiliki gudang, garasi, motor dan mobil yang diperuntukkan bagi kegiatan pertanian. Jenis modal fisik lain yang dimiliki juga meliputi sarana produksi pertanian lainnya, seperti cangkul, sabit, penyemprot pestisida, bak penampung air, dan sepatu lahan. Untuk jenis sarana produksi pertanian yang harganya tidak terlalu mahal biasanya hampir dimiliki oleh seluruh petani. Apabila jenis modal fisik tersebut tidak dimiliki, petani dengan sumber finansial yang cukup memungkinkan untuk melakukan penyewaan.

Sumber finansial yang cukup merupakan modal penting bagi keberlangsungan hidup petani, baik untuk memastikan kebutuhan dasar rumah tangga terpenuhi maupun untuk modal pertanian. Besar dan sumber pendapatan rumah tangga menjadi penentu bagi besaran modal finansial yang dimiliki. Petani dengan kepemilikan lahan lebih dari 1 ha rata-rata memiliki kemampuan finansial yang lebih tinggi dan memiliki investasi berupa tabungan. Petani dengan kepemilikan lahan di atas 1 ha juga memiliki akses yang lebih besar apabila ingin melakukan pinjaman ke lembaga keuangan (bank) karena memiliki jaminan yang layak. Sebaliknya bagi petani dengan kepemilikan lahan di bawah 0,3 ha kondisi finansialnya berada di posisi tidak aman dan sangat rentan dengan defisit.

Modal selanjutnya adalah modal sumber daya alam. Bagi rumah tangga petani modal sumber daya alam yang paling penting adalah lahan pertanian. Posisi tawar petani ditentukan oleh lahan pertanian dengan empat karakterstik yaitu luas lahan, jarak lahan dari sumber air, jarak lahan dari jalan raya atau jalan usaha tani, dan posisi kelerengan lahan. Semakin luas lahan pertanian yang dikuasai petani mengindikasikan bahwa akses petani tersebut terhadap sumber daya alam semakin besar. Hal tersebut berdampak pada keleluasaan pengolahan serta menentukan besarnya sumber pendapatan rumah tangga. Jarak lahan dengan sumber air menentukan besaran usaha dan biaya yang dibutuhkan ketika menghadapi bencana iklim kekeringan. Jarak lahan dengan jalan raya atau jalan usaha tani menentukan kemudahan akses petani ke lahan baik untuk aktivitas budidaya maupun panen. Lahan yang dekat dengan jalan raya maupun jalan usaha tani juga memiliki nilai jual yang lebih tinggi sehingga pemiliknya memiliki posisi tawar yang lebih menguntungkan. Selain luas dan jarak, posisi kelerengan lahan juga penting bagi petani. Posisi lahan di lereng yang miring lebih rawan terhadap kondisi iklim terutama saat musim hujan karena rentan dengan bahaya erosi. Sebaliknya posisi lahan di lokasi yang datar memberikan kemudahan dalam proses pengolahannya.

Berdasarkan kondisi lima modal di tingkat rumah tangga petani tersbeut, ditemukan bahwa semakin luas lahan yang dikuasai oleh rumah tangga petani maka nilai akses terhadap modal relatif lebih tinggi. Petani dengan penguasaan lahan $\geq 1$ ha memiliki akses yang lebih leluasa terhadap modal manusia, modal sosial, modal fisik, modal finansial, dan modal sumberdaya alam. Sebaliknya bagi yang tidak menguasai lahan modal yang dapat diandalkan adalah modal sosial dan modal manusia. Hal tersebut mengindikasikan bahwa kekhawatiran atas kerentanan terhadap perubahan iklim lebih tinggi bagi rumah tangga petani yang tidak memiliki lahan dan juga petani dengan lahan sempit.

Sesuai dengan kondisi akses terhadap lima modal utama yang telah disebutkan diketahui keterkaitan antara karakteristik rumahtangga petani berdasarkan penguasaan lahan dengan tiga aspek utama kerentanan berdasarkan definisi IPCC (2007) bahwa kerentanan berkaitan dengan tiga hal utama yaitu keterpaparan, sensitivitas, dan kapasitas adaptif masyarakat.

\section{Tingkat Keterpaparan}

Kolopaking (2011) merumuskan dua indikator yang dapat digunakan untuk menilai tingkat keterpaparan dan relevan diterapkan pada rumah tangga petani di dataran tinggi. Indikator pertama adalah kedekatan properti atau sumber mata pencaharian keluarga meliputi rumah, lahan pertanian, sumber mata pencaharian dan properti lainnya terhadap pusat bencana (banjir, bahaya longsor, dan kekeringan). Indikator kedua berhubungan dengan upaya atau langkah-langkah penanganan bencana yang sudah dilakukan dan tingkat keberhasilan (efektivitas) upaya yang dilakukan dalam mengurangi besarnya dampak. Kawasan Dataran Tinggi dieng merupakan kawasan yang telah terpapar kejadian perubahan iklim. Peningkatan curah hujan pada saat bulan basah menyebabkan intensitas kejadian longsor semakin tinggi, sebaliknya pada musim kemarau terjadi kekeringan yang mengancam aktivitas pertanian.

Diketahui bahwa mayoritas penduduk di Dataran Tinggi Dieng bergantung pada sektor pertanian lahan kering berupa pertanian kentang yang memerlukan perlakuan khusus dalam menghadapi kondisi iklim. sebagaimana telah dijelaskan sebelumnya bahwa lokalitas perubahan iklim di Dataran Tinggi Dieng terkait dengan lima kejadian iklim utama yaitu curah yang ekstrem, situasi kekeringan, angin ribut, suhu ekstrem, dan iklim yang sulit diprediksi. Kondisi iklim tersebut memberikan paparan bagi rumah tangga pertanian terutama paparan bagi rumah tempat tinggal, sumber mata pencaharian, lahan pertanian, aset bergerak, dan aset tidak bergerak. Aset bergerak meliputi kendaraan, traktor, dan alatalat pertanian seperti genset, mesin penyemprot, dan lain-lain. Aset tidak bergerak meliputi gudang penyimpanan hasil panen kentang dan kios.

Prediksi dan penjelasan historis mengenai kondisi iklim di Dataran Tinggi Dieng menunjukkan bahwa ancaman perubahan iklim yang terberat yang dialami oleh petani adalah curah hujan yang tinggi dan ancaman kekeringan di musim kemarau. Ancaman iklim tersebut memberikan paparan yang relatif sama bagi keseluruhan wilayah di Dataran Tinggi Dieng dengan karakteristik kawasan yang sama. Tingkat paparan menjadi berbeda jika diperdalam di tingkat rumah tangga. Meskipun di wilayah yang terpapar dengan perubahan iklim namun di tingkat rumah tangga ada yang masuk kategori rentan dan tidak rentan. Hal ini dinilai berdasarkan status penguasaan lahan pada lima kategori rumah tangga.

Lima kategori rumah tangga petani di Dataran Tinggi Dieng seluruhnya terpapar oleh dampak perubahan iklim. Perbedaannya adalah rumah tangga dengan penguasaan lahan semakin sedikit atau bahkan tidak menguasai lahan memiliki tingkat keterpaparan yang lebih tinggi. Hal tersebut disebabkan efektifitas penanganan dampak keterpaparan perubahan iklim yang lebih rendah dibanding rumah tangga penguasa lahan yang memiliki aset. Kondisi yang demikian menunjukkan bahwa meskipun keterpaparan berkaitan erat dengan properti yang dikuasai di tingkat rumah tangga, namun keterpaparan tersebut dapat direduksi apabila rumah tangga memiliki efektifitas yang baik terhadap penanganan dampak yang ditimbulkan oleh perubahan iklim.

\section{Tingkat Sensitivitas}

Tingkat sensitivitas menunjukkan derajat suatu sistem yang terpengaruh oleh perubahan iklim dan bagaimana sistem tersebut mampu responsif dengan perubahan. Sistem berkaitan dengan konteks sosial dan ekonomi dari area yang terkena dampak. Perubahan iklim memberikan pengaruh yang 
berbeda terhadap kelompok rumah tangga di Dataran Tinggi Dieng, hal tersebut dikarenakan perbedaan tingkat sensitivitas terhadap ancaman iklim. rumah tangga dengan kategori non-penguasa lahan atau yang mayoritas menjadi buruh tani merupakan kelompok yang paling sensitif terhadap ancaman perubahan iklim. Kelompok non-penguasa lahan memiliki ancaman yang tinggi akibat kehilangan mata pencaharian, tidak memiliki jaminan keamanan (berupa asuransi, jaminan kesehatan, jaminan pendidikan, dll), kerusakan properti rumah tangga, tidak memiliki investasi maupun tabungan, juga rendahnya akses terhadap informasi. Sebaliknya bagi petani dengan penguasa lahan, semakin luas lahan yang dikuasai petani semakin memiliki jaminan keamanan berupa asuransi, pendidikan yang lebih baik, ada investasi dan tabungan, akses informasi lebih terbuka, dan kemungkinan mobilitas lebih tinggi. Pada kasus petani di dataran tinggi, tingkat sensitivitas tersebut berkaitan dengan 9 aspek yaitu sumber pendapatan utama pertanian, sumber pendapatan sampingan, pengeluaran rumah tangga, investasi/tabungan rumah tangga, kondisi keamanan/tingkat kriminalitas, perubahan lingkungan/ ekosistem, sumber air bersih untuk keluarga, akses air bersih ketika terjadi bencana iklim, dan sumber air untuk pertanian.

Kelompok rumah tangga non-penguasa lahan dan rumah tangga dengan penguasaan lahan sempit merupakan kelompok yang paling sensitif terhadap dampak negatif perubahan iklim. Sebaliknya petani dengan penguasaan aset yang lebih banyak termasuk menguasai lahan lebih luas mampu lebih responsif terhadap sensitivitas dampak perubahan iklim. Sensitivitas dibentuk karena tren pertanian kentang di Dataran Tinggi yang berkontribusi terhadap pengingkatan skala resiko iklim karena terjadi dengan cepat dan dalam skala masif. Pembukaan lahan untuk pertanian mengubah fungsi ekosistem yang seharusnya menjadi penyangga wilayah. Selain itu, pertumbuhan penduduk yang tinggi juga tidak dipungkiri meningkatkan kebutuhan atas tanah dan kendaraan serta kebutuhan lainnya sehingga wilayah dapat lebih sensitif terhadap perubahan iklim.

Perubahan iklim yang menyebabkan perubahan musim sukar diprediksi menimbulkan dampak negatif bagi kegiatan pertanian berupa ancama hasil panen, kebutuhan biaya budidaya yang semakin meningkat, dan ketidakpastian pasar. Hal ini terutama akan membawa dampak bagi mata pencaharian petani miskin (golongan non-penguasa lahan dan penguasa lahan sempit $<0,3$ ha serta membawa dampak bagi harga hasil pertanian. Selanjutnya kondisi tersebut menambah beban bagi rumah tangga petani miskin yang telah sulit membeli kebutuhan pokok. Pendapatan yang tidak menentu karena ketergantungan dipekerjakan oleh penguasa lahan serta kenaikan harga dapat semakin menyulitkan mereka. Meskipun diketahui bahwa kelompok rumah tangga petani miskin menjadi sasaran berbagai program pengentasan kemiskinan dari pemerintah seperti Raskin, BLSM, BOS, Jamkesmas, dan lain-lain, namun program-program tersebut seringkali tidak tepat sasaran. Bantuan program dari pemerintah belum dapat diandalkan untuk menjadi alat dalam menghadapi perubahan iklim. Meskipun telah ada program namun kelompok rumah tangga miskin masih tetap sensitif terhadap perubahan iklim.

Sensitivitas merupakan keterkaitan antara ancaman iklim dengan konteks sosial ekonomi dari sistem yanng terkena dampak. Fenomena kelompok rumah tangga yang paling sensitif terhadap perubahan iklim adalah rumah tangga non-penguasa laha atau pun penguasa lahan $<0,3$ ha yang terancam keberlanjutannya melakukan kegiatan pertanian. Masyarakat miskin penguasa lahan $<0,3$ ha sensitif terhadap harga-harga sarana produksi pertanian dan piaya pengolahan lahan. Akibatnya penguasaan lahan yang sempit mendorong mereka untuk menjual atau menyewakan lahannya kepada petani yang memiliki modal lebih besar. Setelahnya mereka memilih untuk bekerja di tempat petani yang membeli atau menyewa lahannya, atau pilihan lain adalah bekerja di sektor informal di luar sektor pertanian.

\section{Kapasitas Adaptif}

Kapasitas adaptif merupakan potensi atau kemampuan suatu sistem mampu beradaptasi dengan adanya perubahan iklim (diantaranya keberagaman iklim dan cuaca ekstrem), terhadap potensi bahaya sedang, mengambil manfaat atas kesempatan atau dalam menghadapi konsekuensi-konsekuansinya (IPCC, 2007). Disebutkan oleh UN-HABITAT, UNDP, dan UNEP (2013) bahwa kapasitas adaptasi merujuk pada aksi baik individu maupun bersama-sama yang dilakukan oleh rumah tangga, masyarakat, organisasi atau lembaga untuk meminimalkan potensi dampak perubahan iklim. Kualitas yang membantu kapasitas beradaptasi suatu sistem merupakan kombinasi dari elemen-elemen fisik dan sosial kelembagaan yang mendukung kemampuan sistem yang beradaptasi terhadap perubahan iklim.

Kapasitas adaptif rumah tangga petani di Dataran Tinggi Dieng dinilai dari 6 aspek yaitu sistem peringatan dini, upaya persiapan untuk menghadapi bencana, upaya saat menghadapi bencana, kerjasama dengan pihak lain, upaya setelah menghadapi bencana, dan dukungan sistem kelembagaan. Keenam aspek penilaian kapasitas adaptif tersebut lebih kuat pada rumah tangga petani yang menguasai lahan lebih luas. Pada rumah tangga petani dengan penguasaan lahan di atas 0,5 ha tingkat kapasitas adaptifnya lebih tinggi dibanding dengan rumah tangga yang menguasai $>0,3$ ha dan bahkan non-penguasa lahan.

Kerentanan terhadap perubahan iklim lebih tinggi pada rumah tangga - rumah tangga dengan penguasaan lahan semakin sempit (dibawah 0,3 ha hingga non-penguasa lahan). Hal ini disebabkan terdapat kecenderungan bahwa semakin luas penguasaan lahan memberikan kemungkinan akses yang lebih luas juga terhadap aset-aset yang ada. Bagi penguasa lahan luas, kerugian akan dampak perubahan iklim terhadap kegiatan pertanian yang dilaksanakan dapat ditutupi dengan adanya aset lain yang dikuasai.

Penelaahan kerentanan terhadap perubahan iklim pada aras rumah tangga dengan melihat keterhubungan antara aspek keterpaparan, sensitivitas, dan kapasitas adaptif dipengaruhi oleh kemampuan rumah tangga atau daya kreatif rumah tangga untuk menghadapi tantangan iklim. Selain itu hal terpenting adalah bagaimana rumah tangga tersebut dapat membuat jaringan sosial yang menjadi modal bagi mereka untuk memperoleh informasi, termasuk informasi pekerjaan untuk bertahan hidup. Meskipun kerentanan rumah tangga bukan acuan bagi tingkat kerentanan sebuah komunitas terhadap perubahan iklim, namun analisa kerentanan perubahan iklim di tingkat rumah tangga lebih relevan dengan tujuan penanganan terhadap dampak perubahan iklim. Hal ini disebabkan upayaupaya bertahan hidup terutama pada komunitas petani dengan penguasaan lahan sempit dan buruh tani di Dataran Tinggi Dieng lebih menarik diri dari perkumpulan komunitas dan berfokus pada upaya pemenuhan kebutuhan hidup.

Menurut Smit dan Wandel (2006) pada level komunitas yang lebih terpapar dan sensitif terhadap stimulus iklim akan mengalami tingkat kerentanan yang lebih tinggi, namun apabila kapasitas adaptifnya bagus maka kerentanannya dapat tereduksi. Hal ini memberikan satu konsekuensi bahwa suatu komunitas dapat memiliki ketahanan terhadap dampak 
perubahan iklim apabila komunitas tersebut memiliki kapasitas adaptasi yang baik. Namun demikian kondisi kapasitas adaptif yang bagus di tingkat komunitas di Dataran Tinggi Dieng tidak dapat digeneralisir berlaku dalam setiap satuan rumah tangga dalam komunitas tersebut karena penguasaan aset atau sumber daya bersifat individual yang terorganisir dalam rumah tangga. Semakin besar aset yang dikuasai oleh rumah tangga petani maka kerentanan terhadap perubahan iklim semakin dapat tereduksi dan sebaliknya.

\section{Strategi Adaptasi Petani terhadap Perubahan Iklim}

Adaptasi pada tingkat rumah tangga petani dalam menghadapi kondisi iklim yang tidak menentu ditentukan oleh seberapa banyak aset yang dimiliki oleh rumah tangga tersebut. Pada dasarnya setiap rumah tangga memiliki kapasitas adaptif. Namun demikian intensitas kekuatan kapasitas adaptif sangat ditentukan dari jumlah aset yang dikuasai terutama lahan pertanian. Semakin luas lahan pertanian dan aset yang dikuasai maka upaya adaptasi yang dilakukan menjadi semakin mudah. Hal ini disebabkan adaptasi berhubungan erat dengan sistem sosial dan ekonomi yang dihadapi. Sebagaimana penjelasan lima aset yang telah dijelaskan sebelumnya, petani dengan penguasaan lahan di atas 0,5 ha leboh memiliki akses terhadap berbagai aset baik sumber daya alam, sumber daya manusia, finansial, fisik, maupun sosial.

Pada konteks rumah tangga petani kentang di Dataran Tingi Dieng, upaya adaptasi dilakukan di berbagai aspek terutama terkait dengan kebutuhan dasar yakni berhubungan dengan mata pencaharian, pangan, dan kesehatan. Adaptasi mata pencaharian lebih mengarah pada upaya adaptasi yang dilakukan untuk kegiatan pertanian dan pengalihannya terhadap kegiatan lain apabila pertanian tidak dapat lagi diandalkan. Aspek pangan terkait dengan upaya pemenuhan kebutuhan pangan yang sifatnya fluktuatif terutama pada rumah tangga petani dengan aset rendah termasuk buruh tani. Pada aspek kesehatan, adaptasi berhubungan dengan kondisi sanitasi baik di lingkungan rumah tangga maupun komunitas.

\section{Adaptasi Mata Pencaharian}

1. Pada musim kemarau normal terjadi kekurangan air bagi petani yang lahannya jauh dari sumber air. Upaya antisipasi adalah melakukan pengambilan air dari sungai atau telaga yang jaraknya berkilo-kilo meter. Bagi petani yang menggarap lahan sangat jauh dari sumber air akan memilih untuk tidak menanam pada musim kemarau dan bahkan hanya menanam satu kali setahun.

2. Pada musim hujan terutama di Bulan November Desember - Januari petani mengantisipasi musim hujan dengan tidak menanam atau memajukan bulan tanam. Pada Bulan November - Januari tanaman kentang petani rentan dengan guyuran hujan dan angin ribut yang dapat sewaktu-waktu terjadi. selain itu sebagian petani juga mengganti jenis tanaman lain selain kentang yaitu tanaman hortikultur berupa kol, wortel. Bagi pbetani yang memajukan waktu tanam harus mempersiapkan modal yang cukup besar terutama untuk menyediakan benih karena implikasi dari pergeseran musim tanam adalah kemungkinan ketiadaan benih. Jika benih tidak tersedia maka petani akan absen menanam.

3. Pergeseran musim disiasati oleh petani lebih ke arah teknis pengendalian hama dan penyakit, petani menggunakan patokan kalender islam dimana diperkirakan setiap tanggal 28 Bulan Syawal merupakan awal musim hujan.

4. Terkait kondisi iklim yang tidak menentu dilakukan oleh rumah tangga petani dengan: (a) mencari benih kentang yang bagus; (b) menanam dengan kapasitas yang tidak terlalu banyak; (c) membuat selingan tanaman hortikultur lain selain kentang, seperti wortel dan sayuran; (d) pada musim penghujan petani memilih pupuk yang tidak banyak mengandung unsur $\mathrm{N}$ (Nitrogen) dan pada musim kemarau menggunakan pupuk dengan kandungan $\mathrm{N}$ yang lebih tinggi. Jenis adaptasi yang sifatnya teknis ini lebih mudah dilakukan oleh rumah tangga dengan kepemilikan aset tinggi karena selain tersedia modal, mereka biasanya sudah memiliki rencana apabila terjadi kondisi musim yang tidak diharapkan. Sebaliknya bagi rumah tangga dengan aset rendah maka jenis adaptasi ini merupakan pilihan yang berat meskipun mereka tahu bahwa demi keberlanjutan usaha tani pilihan adaptasi ini perlu dilakukan, namun apabila dipaksakan akhirnya dapat mengantar mereka pada jerat hutang.

5. Bagi rumah tangga petani dengan penguasaan lahan sempit $(0,1-0,3$ ha), salah satu pilihan beradaptasi dengan kondisi musim yang ada adalah dengan menyewakan atau menjual lahannya kepada petani yang memiliki modal lebih besar. Hal ini dilakukan dengan pertimbangan bahwa menyewakan lahan atau menjual lahan kepada petani lain dirasa lebih menguntungkan dibandingkan mereka harus melakukan budidaya sendiri. Apabila petani menyewakan lahannya, dalam periode 1 tahun pendapatan yang diperoleh dari penyewaan lahan berkisar antara Rp 3.000.000,00 - Rp 4.000.000,00 ditambah dengan penghasilan serabutan yang dapat mereka peroleh dari menjadi buruh di tempat petani lain. Kondisi tersebut dirasa lebih menguntungkan dibandingkan mereka melakukan budidaya pertanian sendiri dengan modal yang berlipat-lipat besarnya.

6. Bagi rumah tangga petani yang telah menyewakan atau menjual lahannya, banyak diantaranya yang menjadi ojek pengangkut kentang.

\section{Adaptasi Pangan}

Kebutuhan akan pangan merupakan kebutuhan pokok bagi masyarakat, tidak terkecuali bagi petani di Dataran Tinggi Dieng. Apabila kebutuhan ini belum tercukupi, mereka tidak akan fokus memperhatikan kebutuhan lain. Kebutuhan pangan dalam kondisi perubahan iklim yang terjadi di Dataran Tinggi Dieng yang dihadapi oleh rumah tangga petani berkaitan strategi adaptasi mata pencaharian yang dilakukan oleh rumah tangga. Kebutuhan akan makanan bagi rumah tangga petani di Dataran Tinggi Dieng bukan sebagai takaran makan nasi tiga kali sehari saja. Suhu yang dingin membentuk pola kebiasaan makan yang khas. Pada pagi hari, sembari menghangatkan badan di depan tungku atau anglo, setiap anggota rumah tangga menikmati seduhan kopi atau teh panas yang dilengkapi dengan camilan baik berupa gorengan maupun makanan ringan. Mereka menyebutnya dengan medangan. Makan nasi biasanya dilakukan ketika berada di lahan pertanian pada pukul 10.00 pagi atau disebut dengan puluk dan juga sore atau malam hari. Pola makan nasi petani cenderung dua kali sehari.

Pola tersebut hampir merata bagi rumah tangga-rumah tangga petani yang ada. Hal yang membedakan adalah dari tingkat ketersediaan pangan yang ada di dalam suatu rumah tangga. Klasifikasi rumah tangga berdasarkan tingkat penguasaan 
lahannya telah menentukan bagaimana upaya adaptasi yang dilakukan dalam rangka menghadapi dampak iklim yang melanda di kawasan mereka. Bagi rumah tangga petani dengan penguasaan lahan di atas 0,5 ha dapat dikatakan untuk kebutuhan pangan ini relatif masih aman karena terpenuhi dari penghasilan pertaniannya yang masih cukup. Jenis medangan yang tersedia juga lebih bervariasi dan disediakan tidak hanya untuk kebutuhan pagi hari atau satu hari saja tetapi distok untuk beberapa hari. Sebaliknya, pada rumah tangga dengan penguasaan lahan di bawah 0,5 ha atau bahkan non penguasa lahan (buruh tani), kebutuhan pangan untuk medangan tidak menjadi prioritas ketersediaannya. Pangan lebih diproritaskan untuk pangan pokok nasi dan lauk.

\section{Adaptasi Kesehatan}

Hal yang mengkhawatirkan pada aspek kesehatan adalah pada lingkungan dusun yang jauh yakni kondisi sanitasinya relatif lebih buruk dibandingkan dengan area-area yang dekat dengan kota kecamatan. Pada lokasi penelitian di Desa Batur, wilayah dusunnya khususnya di Dusun Tieng, Njlegong, Mbakalan, merupakan wilayah dengan kondisi kesehatan yang masih perlu mendapatkan perhatian ketat. Aspek sanitasi sekaligus sarana dan prasarana kesehatan masih minim, banyak warganya yang masih membuang hajat di sungai. Selain itu dusun yang masih minim kondisi kesehatannya ada di Tlagabang, yang kesulitan akses ke bidan desa karena lokasinya paling jauh (bersentuhan juga dengan wilayah Perhutani). Di Dusun Njlegong, terdapat polindes namun kondisinya tidak terawat dan bangunannya kurang memenuhi syarat. Saat ini untuk Dusun Tlagabang, Majatengah, dan Bandingan menggunakan satu polindes di Tlagabang.

Sub kesehatan desa saat ini masih kurang, misalnya penerapan pola hidup bersih dan sehat (PHBS) yang masih timpang diusahakan. Sebagai contoh pola hidup bersih tetapi masih membuah sampah sembarangan. Hal ini disebabkan oleh kesadaran masyarakat yang masih rendah dalam program pemilahan sampah dan sifat pendanaan yang masih swadaya dan minim. Selama ini pembuangan sampah masih dicampur termasuk sampah pertanian, bangkai, dan pupuk kandang. Demikian juga pada kondisi rumah dan jamban, tidak semua rumah memiliki jamban. Meskipun secara ekonomi memiliki kesejahteraan yang tinggi namun kesadaran kesehatan masih rendah. Biasanya kamar mandi + dapur + peralatan pertanian menjadi satu, dalam beberapa kasus juga bersatu dengan kandang ternak.

Kondisi sanitasi dan air bersih di Desa Batur saat ini ditengarai sudah tercemar kuman dari kualitas A menjadi kualitas C. Semakin wilayahnya jauh dari sumber air maka kondisi airnya semakin buruk. Hal ini diduga terjadi pencemaran di jalan sepanjang aliran air tersebut. Kontaminasi bisa berasal dari proses pengobatan tanaman pertanian dan proses buang sampah sembarangan.Proporsi sampah organik jauh lebih besar dibanding sampah anorganik dan meskipun terurai namun sampah organik ini juga berpengaruh terhadap kondisi sanitasi. Secara umum, kondisi iklim yang tidak menentu akibat fenomena perubahan iklim berpengaruh terhadap aspek kesehatan di seluruh wilayah Dataran Tinggi Dieng. Bentuk-bentuk adaptasi yang dilakukan oleh rumah tangga petani terdorong oleh bagaimana segenap warga di lingkungan tersebut dalam melakukan hal yang sama serta bagaimana kondisi lingkungan yang ada.

\section{KESIMPULAN DAN SARAN}

\section{Kesimpulan}

Perubahan iklim merupakan fenomena global yang memiliki dampak regional serta lokal, termasuk di Dataran Tinggi Dieng. Diketahui telah terjadi peningkatan jumlah hari hujan pada bulan basah dan penurunan jumlah hari hujan dan curah hujan pada bulan kering. Selain itu masyarakat lokal memandang telah terjadi perubahan iklim dilihat dari lima fenomena yang terjadi yaitu: (1) curah hujan yang semakin ekstrem pada musimnya, (2) situasi kekeringan yang melanda pertanian, (3) musim angin ribut, (4) kondisi suhu ekstrem pada Bulan Juli atau Agustus ketika muncul embun upas atau titik salju yang menjadikan tanaman muda menjadi layu dan mati, serta yang paling meresahkan adalah (5) kondisi iklim yang semakin sukar diprediksi.

Strategi adaptasi dalam menghadapi perubahan iklim yang dilakukan oleh petani di Dataran Tinggi Dieng berkaitan dengan tingkat kerentanan yang dihadapi oleh rumah tangga petani. Tingkat kerentanan tersebut meliputi tiga aspek yaitu keterpaparan, sensitivitas, dan kapasitas adaptif yang berkaitan erat dengan akses terhadap modal manusia, modal sosial, modal fisik, modal finansial, dan modal sumberdaya alam. Semakin luas lahan yang dikuasai oleh rumah tangga petani maka nilai akses terhadap modal relatif lebih tinggi dan tingkat kerentanannya semakin rendah. Meskipun kerentanan rumah tangga bukan acuan utama bagi tingkat kerentanan sebuah komunitas terhadap perubahan iklim, namun analisa kerentanan perubahan iklim di tingkat rumah tangga lebih relevan dengan tujuan penanganan terhadap dampak perubahan iklim di wilayah dengan sumber daya alam yang lebih dikuasai oleh individu atau rumah tangga. Hal ini disebabkan upaya-upaya bertahan hidup terutama pada rumah tangga petani dengan penguasaan lahan sempit dan buruh tani di Dataran Tinggi Dieng cenderung lebih menarik diri dari perkumpulan komunitas dan berfokus pada upaya pemenuhan kebutuhan hidup.

\section{DAFTAR PUSTAKA}

Chambers, R, Conway, G. 1991. Sustainable Rural Livelihood: Practical Concept for 21st Century. IDS Discussion Paper 296.

[DNPI] Dewan Nasional Perubahan Iklim. 2012. Direktori dan Informasi Adaptasi Perubahan Iklim. Jakarta (ID): Kelompok Kerja Adaptasi Perubahan Iklim DNPI.

Efendi M, Sunoko Henna R, Sulistya W. 2012. Kajian Kerentanan Masyarkat Terhadap Perubahan Iklim Berbasis Daerah Aliran Sungai (Studi Kasus Sub DAS Garang Hulu). Jurnal Ilmu Lingkungan Volume 10 Issue 1: 8-18 (2012).

Eriksen S, Selboe E. 2012. The Social Organisation of Adaptation to Climate Variability and Global Change: The Case of A Mountain Farming Community in Norway. Journal of Applied Geography. Vol.33, April 2012, Pg. 159-167.

Hefner R. 1999. Geger Tengger : Perubahan Sosial dan Perkelahian Politik. Yogyakarta (ID) : LKIS.

Huberman A. Michael, Miles Mattew B. 1997. Manajemen Data dan Metode Analisis. Dalam Handbook of Qualitative Reserach Edisi Bahasa Indonesia, Denzin Norman K, Lincoln, Yvonna S [Eds], Dariyatno, Badrus 
Samsul Fata, Abi, John Rinaldi [Penerj]. Yogyakarta (ID): Pustaka Pelajar.

[IPCC] Intergovernmental Panel on Climate Change. 2007. Climate Change 2007: Synthesis Report, An Assessment of the Intergovernmental Panel on Climate Change,IPCC Plenary XXVII (Valencia, Spain, 12-17 November 2007).

[Kementan] Kementerian Pertanian. 2011. Pedoman Umum Adaptasi Perubahan Iklim Sektor Pertanian. Jakarta(ID): Badan Penelitian dan Pengembangan Pertanian, Kementerian Pertanian.

- 2010. Road Map Strategi Sektor Pertanian Menghadapi Perubahan Iklim. Jakarta(ID): Badan Penelitian dan Pengembangan Pertanian, Kementerian Pertanian.

Kolopaking L. 2012. Pengembangan Sistem Kelembagaan untuk Meningkatkan Efektivitas Aksi-Aksi Adaptasi dan Mitigasi Perubahan Iklim di DAS Citarum. Disampaikan dalam multistakeholder meeting TA ADB 7189 - Paket E Bandung, 6-7 Agustus 2012.

- 2011. Strategi, Pendekatan, Prosedur Pengembangan Kegiatan Pilot Adaptasi dan Mitigasi Perubahan Iklim di DAS Citarum.Disampaikan dalam Workshop Proses Seleksi Kegiatan Pilot TA ADB 7189 - Paket E, Bandung 14 Juli 2011.

[Koran] Bencana Dieng Dilema Utang Para Juragan Kentang. 201103 Juni. Kompas. Regional: 1 \&15 (Kol.1-5).

Li, Tania M. 2002. Proses transformasi Daerah Pedalaman di Indonesia. Jakarta (ID): Yayasan Obor Indonesia.
Pawitan, Hidayat. 2010. Arti Perubahan Iklim Global dan Pengaruhnya Terhadap Pengelolaan Daerah Aliran Sungai di Indonesia. Makalah pada Ekspose Hasil Litbang Balai Penelitian Kehutanan Solo dengan Tema "Pengelolaan DAS dalam Mitigasi dan Adaptasi Perubahan Iklim di Indonesia" di Surakarta, 28 September 2010.

Pemerintah Kabupaten Banjarnegara. 2012. Road Map

Pemulihan Kawasan Dieng Tahun 2011-2016. Banjarnegara (ID): Tim Kerja Pemulihan Kawasan Dieng Kabupaten Banjarnegara.

Smit B, Wandel J. 2006. Adaptation, Adaptive Capacity and Vulnerability. Global Environmental Change 16 (2006) 282-292.

Tjondronegoro SMP, Wiradi G. 2008. Dua Abad Penguasaan Tanah Pola Penguasaan Tanah Pertanian di Jawa dari Masa ke Masa. Jakarta (ID): Yayasan Obor Indonesia.

Turasih, Adiwibowo S. 2012 Sistem Nafkah Rumah Tangga Petani Kentang di Dataran Tinggi Dieng (Kasus Desa Karangtengah, Kecamatan Batur, Kabupaten Banjarnegara, Jawa Tengah), Sodality: Jurnal Sosiologi Pedesaan, September $2012 \quad$ Hal. 196-207.

[WWF] World Wildlife Fund. 2007. Dampak Perubahan Iklim Terhadap Pengelolaan DAS Citarum. Jakarta (ID): WWF Indonesia.

Yuliati, Yayuk. 2011. Perubahan Ekologis dan Strategi Adaptasi Masyarakat di Wilayah Pegunungan Tengger. Malang (ID): UB Press. 
Lampiran 1. Jumlah Hari Hujan Berdasarkan Bulan di Kecamatan Batur Tahun 1990-2011

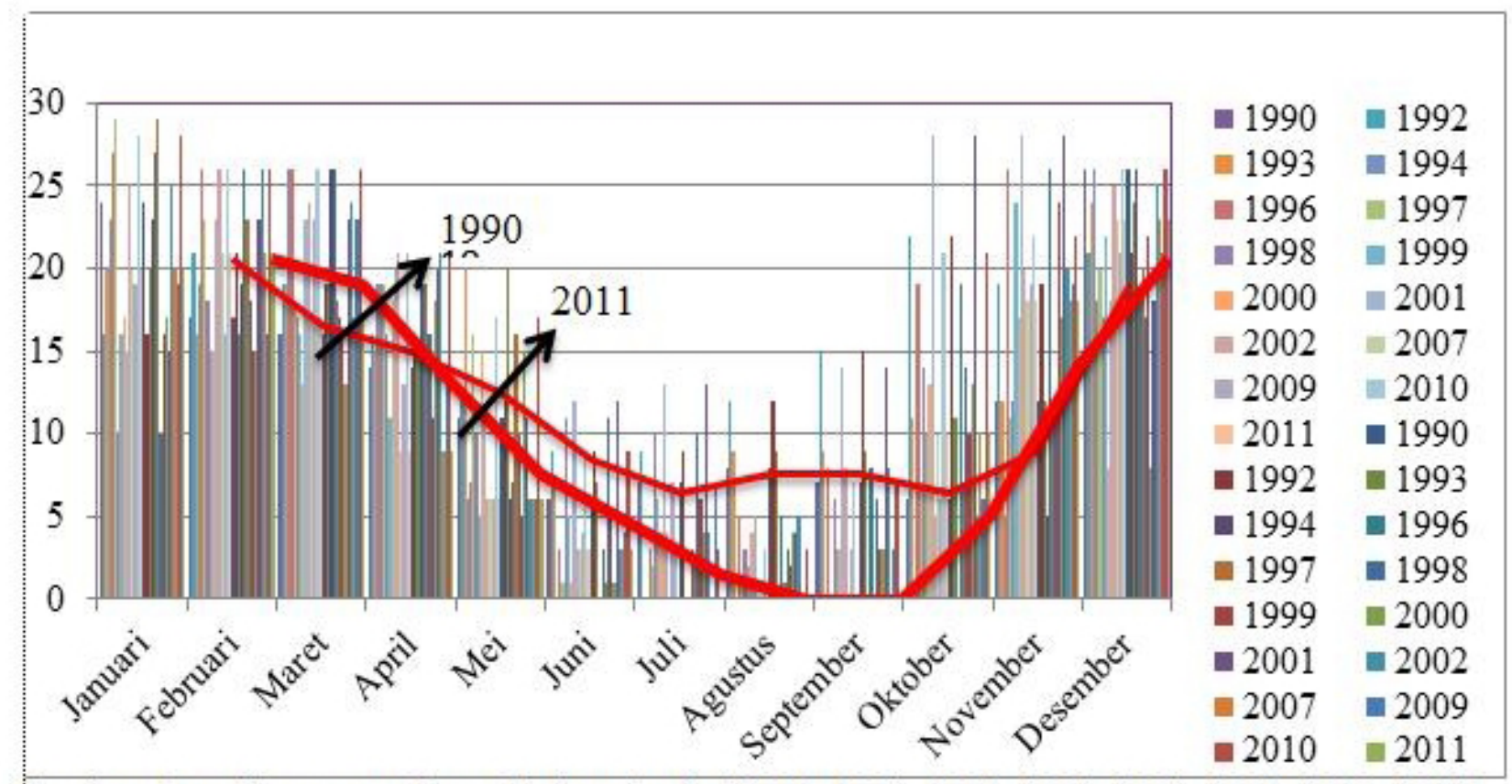

Sumber: Data Kecamatan Batur Dalam Angka (1991, 1994, 1998, 2002, 2004, 2008, 2010, 2012)

Sumber: Data Kecamatan Batur Dalam Angka (1991, 1994, 1998, 2002, 2004, 2008, 2010, 2012)

Lampiran 2. Jumlah dan Rata-rata Curah Hujan Tahunan Periode 1990-2014 di Kecamatan Batur

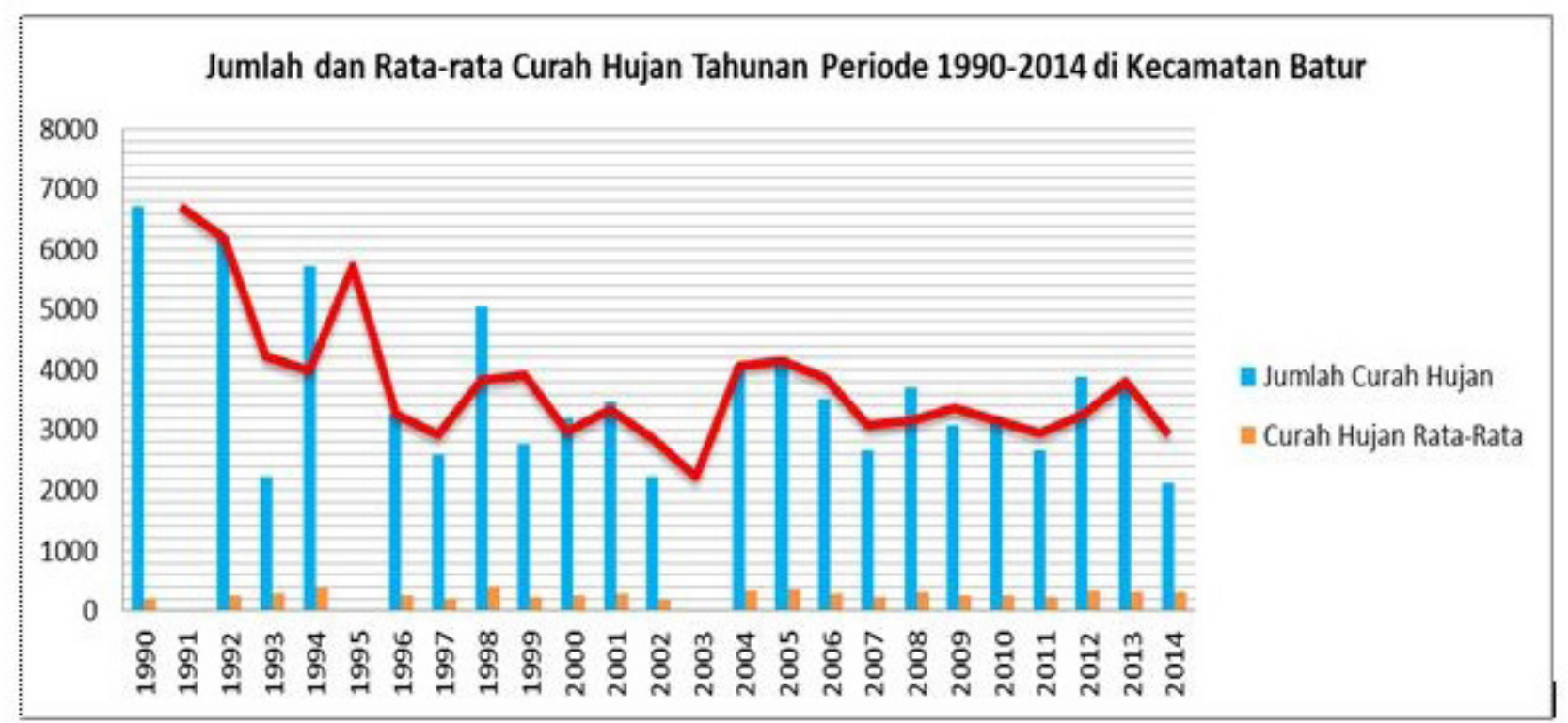

Sumber: Data Kecamatan Batur Dalam Angka (1991, 1994, 1998, 2002, 2004, 2008, 2010, 2012)

BMKG Stasiun Kalilunjar (2004, 2005, 2006, 2008, 2012, 2013, 2014) 